\title{
Penurunan Kadar Enzim Kolinesterase Tenaga Sprayer di Perkebunan Kelapa Sawit
}

\author{
Titi Permatasari Utami ${ }^{1}$, Mona Lestari ${ }^{1 *}$, Novrikasari ${ }^{1}$, Imelda Gernauli Purba ${ }^{2}$, Rico Januar \\ Sitorus $^{1}$, Rizka Faliria Nandini ${ }^{1}$, Poppy Fujianti ${ }^{1}$ \\ ${ }^{1}$ Program Studi Ilmu Kesehatan Masyarakat Fakultas Kesehatan Masyarakat Universitas Sriwijaya, Palembang, Indonesia \\ ${ }^{2}$ Program Studi Kesehatan Likngkungan Fakultas Kesehatan Masyarakat Universitas Sriwijaya, Palembang, Indonesia \\ *Corresponding Author: mona_lestari@unsri.ac.id
}

Info Artikel : Diterima 22 Juni 2020 ; Disetujui 3 Oktober 2020 ; Publikasi 1 April 2021

Cara sitasi (Vancouver): Utami T, Lestari M, Novrikasari N, Purba I, Sitorus R, Nandini R, Fujianti P. Penurunan Kadar Enzim Kolinesterase Tenaga Sprayer di Perkebunan Kelapa Sawit. Jurnal Kesehatan Lingkungan Indonesia [Online]. 2021 Apr;20(1):27-33. https://doi.org/10.14710/jkli.20.1.27-33.

\begin{abstract}
ABSTRAK
Latar belakang: Pestisida golongan organofosfat bersifat menghambat aktivitas enzim kolinesterase di dalam tubuh. Pekerja yang bertugas untuk melakukan penyemprotan pestisida memiliki risiko yang sangat tinggi terkena dampak negatif dari pajanan pestisida. Penelitian ini bertujuan untuk mengetahui faktor risiko penurunan kadar enzim kolinesterase tenaga sprayer di perkebunan kelapa sawit PT. X Kabupaten Musi Banyuasin.

Metode: Penelitian ini menggunakan pendekatan kuantitatif dengan menggunakan rancangan penelitian cross sectional. Sampel pada penelitian ini yaitu sebanyak 113 orang. Pengukuran data dilakukan dengan menggunakan kuesioner dan pemeriksaan kadar enzim kolinesterase.

Hasil: Hasil penelitian menunjukkan bahwa terdapat 3,5\% tenaga sprayer yang mengalami penurunan kadar kolinesterase. Dari hasil analisis bivariat diketahui adanya hubungan antara penggunaan Alat Pelindung Diri (APD) $(p$-value $=0,046)$ dengan penurunan kadar enzim kolinesterase tenaga sprayer. Melalui analisis multivariate diketahui bahwa penggunaan APD merupakan faktor yang paling berhubungan dengan penurunan kadar enzim kolinesterase setelah dikontrol dengan variabel arah angin.

Simpulan: Dapat disimpulkan bahwa penggunaan APD berhubungan erat dengan penurunan kadar enzim kolinesterase sehingga disarankan melengkapi APD yang digunakan saat bekerja dan perlu adanya edukasi yang diberikan kepada tenaga sprayer mengenai faktor keracunan pestisida.
\end{abstract}

Kata kunci: Pestisida; enzim kolinesterase; keracunan pestisida; tenaga sprayer; perkebunan kelapa sawit

\section{ABSTRACT}

Title: The Decrease of Cholinesterase Enzyme Level in Pesticide Sprayers in Palm Oil Plantation

Background: Organophosphate pesticides are inhibiting the activity of the cholinesterase enzyme in human body. Workers in charge of pesticide spraying have a very high risk of being negatively affected by pesticide exposure. This study aims to determine the risk factors for cholinesterase enzyme decline in pesticide sprayers of PT. X Musi Banyuasin Regency.

Method: This study used a quantitative approach using a cross sectional study design. The sample in this study were 113 pesticide sprayers. Data measurements were performed using a questionnaire and examination of cholinesterase enzyme levels.

Result The results showed that there was 3.5\% pesticide sprayers that has decreased cholinesterase enzyme level. From the results of bivariate analysis it is determined that there is a correlation between the use of Personal Protective Equipment (PPE) (p-value =0.046) and declining cholinesterase enzyme level in pesticide 
sprayers. Through multivariate analysis it is determined that the use of PPE is the most related factor in the decrease of cholinesterase enzyme after being controlled with wind direction variables..

Conclusion: It can be concluded that the use of PPE is closely related to the decrease cholinesterase enzyme in pesticide sprayers so it is recommended for the company to provide PPE at work and to educate the sprayers about factors in pesticide poisoning.

Keywords: Pesticides; cholinesterase enzymes; pesticide poisoning; pesticide sprayers; oil palm plantations

\section{PENDAHULUAN}

Kelapa sawit adalah tanaman yang menghasilkan Minyak Kelapa Sawit (MKS) yang merupakan bahan baku utama pembuatan minyak makan. Seperti pada tanaman perkebunan lainnya pertumbuhan tanaman kelapa sawit dapat dipengaruhi oleh keberadaan Organisme Pengganggu Tanaman (OPT). OPT adalah semua organisme yang dapat menyebabkan penurunan potensi hasil yang secara langsung karena menimbulkan kerusakan fisik, gangguan fisiologi dan biokimia, atau kompetisi hara terhadap tanaman budidaya.

Berdasarkan jenis serangannya OPT dibagi menjadi tiga kelompok, yaitu hama, patogen, dan gulma. Upaya pengendalian OPT dapat dilakukan dengan bebagai cara seperti fisik, mekanik, dan kimiawi. Dengan semakin meningkatnya luas lahan pertanian menyebabkan upaya pengendalian OPT secara kimiawi semakin meningkat. Pengendalian OPT secara kimiawi berpotensi merusak lingkungan sehingga diperlukan pengendalian dan pengawasan. Pengendalian dengan menggunakan cara kimia, penggunaan pestisida dengan tidak memperhatikan aturan dosis dan dilakukan secara berulang kali akan menimbulkan beberapa kerugian, antara lain residu pestisida pada produk-produk pertanian atau perkebunan, pencemaran lingkungan, dan keracunan pada hewan dan manusia yang berdampak pada kesehatan. Pekerja yang bertugas untuk melakukan penyemprotan pestisida memiliki risiko yang sangat tinggi terkena dampak negatif dari pajanan pestisida. Hal tersebut dapat terjadi dikarenakan kegiatan pekerjaan berupa penyemprotan pestisida, menyiapkan perlengkapan untuk penyemprotan, mencampur pestisida, serta mencuci peralatan yang digunakan pada saat penyemprotan. ${ }^{1}$ Beberapa faktor juga dapat mempengaruhi kejadian keracunan pestisida pada manusia, terdapat dua faktor yaitu faktor internal berupa umur, status gizi, jenis kelamin, tingkat pendidikan serta pengetahuan mengenai penggunaan pestisida dengan baik dan benar sedangkan faktor eksternal berupa dosis pestisida, lama kerja pekerja, tindakan penyemprotan pada arah angin, waktu penyemprotan, frekuensi penyemprotan dan Alat Pelindung Diri (APD). ${ }^{2}$

PT. X merupakan perusahaan yang bergerak pada bidang perkebunan, salah satu produk perkebunan PT. X adalah kelapa sawit. Dalam memproduksi kelapa sawit PT. X mempekerjakan tenaga sprayer yang berjumlah sekitar 113 orang. Tenaga sprayer tersebut bertugas untuk melakukan pengendalian terhadap OPT yang dapat menghambat pertumbuhan dan mempengaruhi hasil produksi tanaman kelapa sawit. Pada tahun 2012 terdapat kasus keracunan berat pestisida sebesar $2,7 \%$ yang terjadi pada tenaga sprayer di perkebunan kelapa sawit pada wilayah Kecamatan Babat Toman yang disebabkan tidak menggunakan APD pada saat proses pencampuran pestisida kemudian pada tahun 2018 berdasarkan hasil pemeriksaan dari tes kolinesterase pada tenaga sprayer yang dilakukan oleh Hiperkes, jumlah kasus mengalami kenaikan menjadi 3,5\%. Berdasarkan masalah tersebut diperlukan penelitian mengenai "faktor risiko penurunan kadar enzim kolinesterase tenaga sprayer di Perkebunan Kelapa Sawit PT. X Kabupaten Musi Banyuasin”.

\section{MATERI DAN METODE}

Penelitian ini menggunakan pendekatan kuantitatif dengan menggunakan rancangan penelitian cross sectional. Populasi dalam penelitian ini adalah tenaga sprayer di pekebunan kelapa sawit PT. X Kabupaten Musi Banyuasin yang berjumlah sebanyak 113 orang. Sampel pada penelitian menggunakan total populasi. Penelitian dilakukan di perkebunan kelapa sawit PT. X Kabupaten Musi Banyuasin pada bulan Juni sampai Juli 2019. Pengukuran data dilakukan dengan menggunakan kuesioner dan pemeriksaan kadar enzim kolinesterase. Pemeriksaan kadar kolinesterase dilakukan dengan menggunakan alat ukur berupa The Lovibond Cholinesterase Test Kit $A F-267$. Pemeriksaan kolinesterase darah tenaga sprayer yang dilakukan oleh Hiperkes yang bekerja sama dengan PT.X. Analisis data yang dilakukan dalam penelitian ini univariat, bivariat dengan uji fisher exact dan multivariat uji regresi logistik ganda model prediksi.

\section{HASIL DAN PEMBAHASAN}

Berdasarkan hasil penelitian pada tabel 1 dapat diketahui bahwa dari 113 tenaga sprayer terdapat 3,5\% pekerja yang mengalami penurunan kadar enzim kolinesterase. Sementara mayoritas pekerja berusia $\geq$ 36 tahun $(59,3 \%)$, yang didominasi oleh laki-laki $(81,4 \%)$, dengan tingkat pengetahuan yang kurang sebesar 18,6\%. Pekerja dengan masa kerja $>10$ tahun sebanyak 45 orang $(39,8 \%)$. Mayoritas pekerja melakukan penyemprotan dengan tidak memperhatikan arah angin yaitu sebanyak 70 orang $(61,9 \%)$, dan memiliki frekuensi penyemprotan $>2$ kali dalam seminggu sebesar 74,3\%. Serta, masih ada 
pekerja yang tidak menggunakan APD dengan baik sebanyak 28 orang $(24,8 \%)$.

Berdasarkan tabel 2, hasil analisis bivariat menunjukkan bahwa terdapat hubungan antara penggunaan APD ( $p$-value $=0,046)$ dengan penurunan kadar enzim kolinesterase tenaga sprayer. Sementara itu, tidak ada hubungan antara usia ( $p$ value $=1,000)$, jenis kelamin $(p$-value $=0,566)$, tingkat pengetahuan ( $p$-value $=0,107)$, masa kerja ( $p$ value $=1,000)$, arah angin $(p$-value $=0,320)$, dan frekuensi penyemprotan $(p$-value $=0,051)$ dengan penurunan kadar enzim kolinesterase tenaga sprayer.

Hasil analisis bivariat dengan uji fisher exact menunjukkan bahwa tidak ada hubungan yang bermakna secara statistik antara usia dengan kadar enzim kolinesterase. Kadar enzim kolinesterase pada anak-anak dan orang dewasa (usia diatas 20 tahun) memiliki perbedaan baik dalam keadaan terpapar dengan pestisida organofosfat dan karbamat maupun selama tidak terpapar dengan pestisida organofosfat dan karbamat. ${ }^{3}$

Penelitian yang dilakukan oleh Zuraida menyatakan bahwa tidak ada hubungan yang bermakna antara umur $18-54$ tahun dan umur $\geq 55$ tahun dengan tingkat keracunan terhadap penurunan kadar enzim kolinesterase. ${ }^{4}$ Selain itu, hasil penelitian yang dilakukan oleh Rahmawati dan Martiana tentang pengaruh faktor karakteristik petani dan metode penyenyemprotan terhadap kadar kolinesterase bahwa hasil analisis yang didapatkan dengan menggunakan regresi linier didapatkan dengan nilai signifikan 0,194 yang berarti tidak ada pengaruh antara umur dengan kadar kolinesterase. ${ }^{5}$

Tabel 1. Deskripsi variabel Penelitian

\begin{tabular}{|c|c|c|c|}
\hline No. & Variabel & $\begin{array}{c}\text { Frekuensi } \\
\mathrm{n}=113\end{array}$ & $\%$ \\
\hline \multirow[t]{3}{*}{1} & Kadar Enzim Kolinesterase & & \\
\hline & Keracunan & 4 & 3,5 \\
\hline & Normal & 109 & 96,5 \\
\hline \multirow[t]{3}{*}{2} & Usia & & \\
\hline & $\geq 36$ Tahun & 67 & 59,3 \\
\hline & $<36$ Tahun & 46 & 40,7 \\
\hline \multirow[t]{3}{*}{3} & Jenis Kelamin & & \\
\hline & Laki-laki & 92 & 81,4 \\
\hline & Perempuan & 21 & 18,6 \\
\hline \multirow[t]{3}{*}{4} & Tingkat Pengetahuan & & \\
\hline & Kurang & 21 & 18,6 \\
\hline & Baik & 92 & 81,4 \\
\hline \multirow[t]{3}{*}{5} & Masa Kerja & & \\
\hline & $>10$ Tahun & 45 & 39,8 \\
\hline & $\leq 10$ Tahun & 68 & 60,2 \\
\hline \multirow[t]{3}{*}{6} & Arah Angin & & \\
\hline & Melawan arah angin & 70 & 61,9 \\
\hline & Searah arah angin & 43 & 38,1 \\
\hline \multirow[t]{3}{*}{7} & Frekuensi Penyemprotan & & \\
\hline & $>2$ kali & 84 & 74,3 \\
\hline & $\leq 2 \mathrm{kali}$ & 29 & 25,7 \\
\hline \multirow[t]{3}{*}{8} & Penggunaan APD & & \\
\hline & Tidak baik & 28 & 24,8 \\
\hline & Baik & 85 & 75,2 \\
\hline
\end{tabular}

Tabel 2. Analisis Bivariat

\begin{tabular}{|c|c|c|c|c|c|c|c|}
\hline \multirow[b]{2}{*}{ No } & \multirow[b]{2}{*}{ Variabel } & \multicolumn{2}{|c|}{ Kadar Enzim Kolinesterase } & \multirow[b]{2}{*}{ p-value } & \multirow[b]{2}{*}{$\mathbf{P R}$} & \multicolumn{2}{|c|}{$95 \% \mathrm{CI}$} \\
\hline & & $\begin{array}{c}\text { Keracunan } \\
n=4\end{array}$ & $\begin{array}{c}\begin{array}{c}\text { Normal } \\
n=109\end{array} \\
\end{array}$ & & & Lower & Upper \\
\hline \multirow[t]{3}{*}{1} & Usia & & & & & & \\
\hline & $\geq 36$ Tahun & $2(3,0 \%)$ & $65(97,0 \%)$ & 1,000 & 0,687 & 0,100 & 4,700 \\
\hline & $<36$ Tahun & $2(4,3 \%)$ & $44(95,7 \%)$ & & & & \\
\hline \multirow[t]{3}{*}{2} & Jenis Kelamin & & & & & & \\
\hline & Laki-laki & $3(3,3 \%)$ & $89(96,7 \%)$ & 0,566 & 0,685 & 0,075 & 6,261 \\
\hline & Perempuan & $1(4,8 \%)$ & $20(95,2 \%)$ & 0,500 & 0,003 & $0,0 / 3$ & 0,201 \\
\hline \multirow[t]{3}{*}{3} & Tingkat Pengetahuan & & & & & & \\
\hline & Kurang & $2(11,8 \%)$ & $15(88,2 \%)$ & 0,107 & 5,647 & 0,852 & 37,413 \\
\hline & Baik & $2(2,1 \%)$ & $94(97,9 \%)$ & & & & \\
\hline \multirow[t]{3}{*}{4} & Masa Kerja & & & & & & \\
\hline & $>10$ Tahun & $1(2,2 \%)$ & $44(97,8 \%)$ & 1,000 & 0,504 & 0,054 & 4,692 \\
\hline & $\leq 10$ Tahun & $3(4,4 \%)$ & $65(95,6 \%)$ & & & & \\
\hline \multirow[t]{3}{*}{5} & Arah Angin & & & & & & \\
\hline & Melawan arah angin & $1(1,6 \%)$ & $62(98,4 \%)$ & 0,320 & 0,265 & 0,028 & 2,466 \\
\hline & Searah arah angin & $3(6,0 \%)$ & $47(94,0 \%)$ & & & & \\
\hline \multirow[t]{3}{*}{6} & Frekuensi Penyemprotan & & & & & & \\
\hline & $>2$ kali & $1(1,2 \%)$ & $83(98,8 \%)$ & 0,051 & 0,115 & 0,012 & 1,063 \\
\hline & $\leq 2$ kali & $3(10,3 \%)$ & $26(89,7 \%)$ & & & & \\
\hline \multirow[t]{3}{*}{7} & Penggunaan APD & & & & & & \\
\hline & Tidak baik & $3(10,7 \%)$ & $25(89,3 \%)$ & $0,046^{*}$ & 9,107 & 0,987 & 84,063 \\
\hline & Baik & $1(1,2 \%)$ & $84(98,8 \%)$ & & & & \\
\hline
\end{tabular}

Ket : * (signifikan)

Namun dalam penelitian ini diketahui bahwa terdapat $3,0 \%$ pekerja $\geq 36$ tahun yang mengalami penurunan kadar enzim kolinesterase, sementara terdapat $4,3 \%$ pekerja yang berusia $<36$ tahun yang mengalami penurunan kadar enzim kolinesterase. Menurut International Labor Organization (ILO) 
(1975) yang dikutip oleh Darmawan menjelaskan bahwa pekerja dengan usia muda dibawah 20 tahun mempunyai aktivitas kolinesterase yang relatif lebih cepat turun dibandingkan dengan pekerja dengan usia lebih tua, terutama jika dipengaruhi oleh paparan atau pajanan pestisida yang dapat memperparah terjadinya keracunan. Semakin bertambahnya usia seseorang maka semakin lama pula masa kerja dengan pestisida sehingga berdampak pada banyaknya paparan yang menyebabkan efektifitas sistem kekebalan tubuh semakin berkurang dan mempengaruhi tubuh untuk mengatasi toksisitas suatu zat. ${ }^{6}$

Hasil tabulasi silang diketahui bahwa terdapat 3,3\% pekerja laki-laki yang mengalami penurunan kadar enzim kolinesterase, sementara terdapat $4,8 \%$ pekerja perempuan yang mengalami penurunan kadar enzim kolinesterase. Berdasarkan hasil analisis dengan uji fisher exact diperoleh hasil ( $p$-value = 0,566 ) yang berarti bahwa tidak ada hubungan yang bermakna secara statistik antara jenis kelamin dengan kadar enzim kolinesterase. Hal ini sesuai dengan penelitian yang dilakukan oleh Wicaksono et al dan Zulkildi yang menyatakan bahwa tidak ada hubungan yang bermakna antara jenis kelamin dengan kadar enzim kolinesterase. ${ }^{7,8}$

Penelitian yang dilakukan Mualim menyatakan bahwa kejadian keracunan pestisida pada pekerja lakilaki sebanyak 34 dari 44 orang, sedangkan pada pekerja perempuan sebanyak 7 dari 8 orang. Hal ini sejalan dengan disertasi yang dilakukan Achmadi (1985) menyatakan bahwa terdapat perbedaan aktifitas kolinesterase yang bermakna antara perempuan dan laki-laki pada petani penyemprot hama tanaman pengguna pestisida. Jenis kelamin lakilaki dan wanita mempunyai angka normal aktifitas kolinesterase yang berbeda. Kadar kolinestarese bebas dalam plasma darah laki-laki dewasa normal sekitar $4,4 \mu \mathrm{g} / \mathrm{ml}$. Perempuan rata-rata mempunyai aktifitas kolinesterase darah lebih tinggi dibandingkan dengan laki-laki. Meskipun demikian tidak dianjurkan wanita melakukan penyemprotan pestisida, karena pada saat kehamilan kadar rata-rata kolinesterase cenderung mengalami penurunan. ${ }^{9}$

Berdasarkan hasil dari analisis dengan uji fisher exact menunjukkan bahwa tidak ada hubungan yang bermakna secara statistik antara tingkat pengetahuan dengan kadar enzim kolinesterase. Pengetahuan pemakaian pestisida meliputi bahaya pestisida terhadap manusia dan lingkungan, jalur masuk pestisida, APD yang harus dipakai, waktu dan posisi penyemprotan, serta label tata cara pemakaian pestisida (nama bahan aktif, tanda keracunan, bentuk, cara penyimpanan, dan cara pembuangan limbah). ${ }^{10}$

Hasil penelitian ini sejalan dengan hasil penelitian oleh Utami yang menyatakan bahwa tidak terdapat hubungan antara pengetahuan dengan tindakan dalam penggunaan pestisida dan tingkat keracunan pestisida di Desa Kembang Kuning Kecamatan Cepogo. ${ }^{11}$ Namun hal tersebut tidak sejalan dengan penelitian yang dilakukan oleh
Budiawan bahwa berdasarkan uji chi square yang dilakukan terhadap tingkat pengetahuan dengan kolinesterase petani didapat $(p$-value $=0,002)$ yang berarti bahwa ada hubungan antara tingkat penetahuan dengan kolinesterase petani bawang merah di Ngurensiti Pati. ${ }^{12}$ Penurunan kadar enzim kolinesterase disebabkan oleh masuknya pestisida kedalam tubuh hal tersebut dipengaruhi oleh faktor perilaku petani. Pada kenyataannya banyak tenaga sprayer yang memiliki tingkat pengetahuan yang baik namun berperilaku yang tidak sesuai pada saat di lapangan dimana hal tersebut menyebabkan terjadinya penurunan kadar kolinesterase pada tenaga sprayer yang memiliki pengetahuan baik. Oleh karena itu, perlu dilakukan penyuluhan dan pembinaan tentang pengetahuan pemakaian pestisida yang baik dan benar.

Jumlah tenaga sprayer yang memiliki masa kerja $>10$ tahun sebesar 45 orang $(39,8 \%)$ dan tenaga sprayer yang memiliki masa kerja $\leq 10$ tahun sebanyak 68 orang $(60,2 \%)$. Hasil uji statistik diperoleh nilai $p$-value $=1,000$ hal ini berarti bahwa tidak ada hubungan yang bermakna secara statistik antara masa kerja dengan kadar enzim kolinesterase. Hal tersebut sama dengan penelitian sebelumnya yang dilakukan oleh Mualim yang mengatakan bahwa masa kerja tidak mempunyai pengaruh yang bermakna terhadap kejadian keracunan pestisida.9 Sejalan dengan penelitian Rustia (2010) dan Kurniasih (2013) juga menyatakan bahwa tidak ada hubungan antara masa kerja dengan keracunan pestisida. ${ }^{1,13}$

Namun hal tersebut bertentangan dengan hasil penelitian yang dilakukan oleh Samosir, et al. yang menyatakan bahwa terdapat hubungan antara masa kerja dengan kadar kolinesterase pada petani padi pengguna pestisida. ${ }^{14}$ Semakin lama pekerja kontak langsung dengan pestisida maka akan lebih lama terpapar pestisida yang menyebabkan semakin tingginya risiko kecarunan karena bioakumulasi pestisida di dalam tubuh.

Hasil analisis dengan uji fisher exact pada penelitian ini menunjukkan bahwa tidak ada hubungan yang bermakna secara statistik antara tindakan peyemprotan pada arah angin dengan kadar enzim kolinesterase. Hasil penelitian yang dilakukan oleh Osang, et al. (2016) terdapat hubungan yang signifikan antara praktik penyemprotan pestisida terhadap arah angin dengan kadar kolinesterase darah $(p$-value $=0,004) .{ }^{15}$ Penyemprotan yang tidak memperhatikan arah angin menyebabkan cairan semprot pestisida mengenai tubuh pekerja sehingga akan lebih mudah terjadi keracunan terlebih jika tanaman yang disemprot memiliki bentuk yang tinggi. Penyemprotan yang tidak mempertimbangkan arah angin juga akan mengakibatkan pencemaran lahan pertanian akibat akumulasi bahan aktif dari pestisida. ${ }^{16}$ Namun pernyataan tersebut tidak sejalan dengan hasil penelitian yang dilakukan oleh Samosir, et al. yang menyatakan bahwa tidak ada hubungan antara cara penyemprotan pestisida melawan arah 
angin dengan kejadian keracunan pada petani hortikultura di Kecamatan Ngablak Kabupaten Magelang. ${ }^{14}$

Berdasarkan hasil analisis dengan uji fisher exact pada penelitian ini menunjukkan bahwa tidak ada hubungan yang bermakna secara statistik antara frekuensi penyemprotan dengan kadar enzim kolinesterase. Namun, pada hasil analisis mulivariat menunjukkan bahwa variabel frekuensi penyemprotan merupakan salah satu faktor risiko terhadap terjadinya penurunan enzim kolinesterase dengan nilai $\mathrm{PR}=$ 3,250 (95\% CI; 1,160-15,055) pada populasi setelah dikontrol oleh variabel arah angin. Berdasakan hasil penelitian Kurniasih, et al. menyatakan tidak terdapat hubungan antara frekuensi menyemprot dengan kejadian penurunan kadar kolinesterase. ${ }^{1}$ Sedangkan, berdasarkan hasil penelitian yang dilakukan oleh Budiawan yang menyatakan ada hubungan antara tingkat frekuensi penyemprotan dengan kolinesterase petani bawang merah di Ngurensiti Pati. ${ }^{12}$ Hal tersebut dikarenakan paparan pestisida dengan frekuensi yang sering dan interval waktu yang singkat menyebabkan residu pestisida dalam tubuh menjadi meningkat. ${ }^{17}$ Oleh karena itu, frekuensi penyemprotan pestisida sebaiknya dilakukan terjadwal dan tepat waktu untuk mengurangi paparan dan mencegah tingkat keracunan menjadi semakin buruk. ${ }^{18}$

Hasil analisis dengan uji fisher exact menunjukkan bahwa ada hubungan yang bermakna secara statistik antara penggunaan APD dengan kadar enzim kolinesterase. Hal ini sejalan dengan penelitian yang dilakukan oleh Lusiana yang menyatakan bahwa ada hubungan antara penggunaan alat pelindung diri (APD) dengan keracnan pestisida $(p$-value $=0,052) .{ }^{19}$ Selain itu, Mualim menyatakan bahwa pemakaian APD tidak lengkap pada petani mempunyai risiko untuk terjadi keracunan 9,873 kali dibandingkan dengan pemakaian APD lengkap pada tenaga penjual pestisida. ${ }^{9}$ Hasil multivariat pada penelitian ini diperoleh hasil penggunaan APD merupakan faktor risiko yang paling dominan terhadap terjadinya penurunan kadar enzim kolinesterase setelah dikontrol oleh variabel arah angin dengan nilai PR 4,365 (95\% CI; 1,732-19,842).

Tabel 3. Analisis Multivariat

\begin{tabular}{ccc}
\hline Variabel & p-value & PR (95\% CI) \\
\hline Arah Angin & 0,085 & $1,087(0,926-9,644)$ \\
Frekuensi Penyemprotan & 0,037 & $3,250(1,160-15,055)$ \\
Penggunaan APD & 0,035 & $4,365(1,732-19,842$ \\
\hline
\end{tabular}

Hasil analisis multivariat menunjukkan bahwa variabel yang berhubungan secara bermakna dengan kejadian penurunan kadar enzim kolinesterase adalah frekuensi penyemprotan dan penggunaan APD. Sedangkan variabel arah angin adalah variabel confounding. Variabel yang paling dominan berpengaruh terhadap terjadinya penurunan kadar enzim kolinesterase adalah penggunaan APD dengan PR 4,365, artinya pekerja dengan pengunaan APD tidak baik berisiko 4,4 kali lebih besar untuk mengalami penurunan kadar enzim kolinesterase dibandingkan dengan pekerja dengan penggunaan APD yang baik setelah dikontrol dengan variabel arah angin pada tingkat kepercayaan $(95 \% \mathrm{CI}$; 1,73219,842) pada populasi.

Hasil penelitian ini sejalan dengan penelitian Neupane, et al (2014) pada petani di Nepal yang menunjukkan bahwa rendahnya kadar enzim kolinesterase disebabkan karena penggunaan APD yang tidak memadai serta personal hygiene yang buruk sehingga menyebabkan pekerja mudah terpapar racun pestisida. ${ }^{20}$ Penelitian Dhananjayan, et al. (2019) pada pekerja wanita di perkebunan teh India juga menyatakan bahwa paparan pestisida dapat meningkatkan kerusakan DNA dan berisiko terhadap genotoksisitas salah satunya disebabkan karena penggunaan APD yang tidak memadai seperti sarung tangan, sepatu bot, kacamata, masker, dan sebagainya. ${ }^{21}$ Penelitian Nassar dan Ribeiro di Sao Paulo, Brazil menjelaskan bahwa ada 2 dari 65 pekerja budidaya tanaman bunga hias di rumah kaca tidak mencuci APD untuk menghindari kerusakan. Sementara itu, kegiatan mandi untuk menjaga kebersihan pribadi tidak dilaporkan sebagai praktik rutin pekerja setelah kontak langsung dengan pestisida. ${ }^{22}$ Penjelasan tersebut memberikan gambaran bahwa meskipun APD telah digunakan namun dengan standar tidak memadai serta kebersihan pribadi pekerja yang buruk dapat meningkatkan risiko terpaparnya pestisida meskipun paparan pestisida biasanya terjadi melalui penghirupan, penyerapan kulit adalah jalur masuk utama di antara petani dan pekerja perkebunan. $^{23}$

Sebuah penelitian yang dilakukan oleh Rural Industries Research and Development Corporation (RIRDC) tahun 2015 melaporkan bahwa hambatan penggunaan APD pada pekerja salah satunya adalah faktor ketidaknyamanan dan ketersediaan untuk penggunaan dalam sehari-hari. ${ }^{24}$ Sedangkan berdasarkan penelitian Cotton, et al. mengungkapkan bahwa sejumlah pekerja $(92,7 \%)$ tidak menggunakan APD berupa pelindung wajah. ${ }^{25}$ Penelitian Magauzi pada pekerja pertanian komersial di Kwekwe, Zimbabwe menyatakan bahwa penggunaan APD berhubungan signifikan dengan aktivitas kolinesterase yang abnormal (OR 2,23; 95\% CI: 1.04 - 4.80). Alasan pekerja tidak menggunakan APD masker wajah adalah karena dianggap menghalangi sistem pernafasan. Penelitian ini juga mengungkapkan bahwa pekerja laki-laki memiliki kemungkinan lebih kecil untuk mengalami aktivitas kolinesterase yang abnormal dibanding perempuan meskipun tidak dibuktikan secara statistik. Pekerja laki-laki dominan terlibat dalam pencampuran, penyemprotan, perbaikan alat, dan pengelolaan pestisida yang menyebabkan adanya kontak langsung dengan pestisida kemudian lebih diprioritaskan untuk pemberian APD. Pemberian APD menjelaskan kemungkinan perbedaan aktivitas abnormal kolinesterase antara pekerja laki-laki dan perempuan. ${ }^{26}$ 
Hasil uji analisis chi square pada penelitian As'ady menunjukkan bahwa terdapat hubungan antara penggunaan APD dengan keluhan kesehatan petani karena masih salah dalam penggunaannya. Baju lengan panjang dan celana panjang yang dipakai pekerja ditekuk saat melakukan pencampuran dan penyemprotan pestisida sehingga menyebabkan partikel-partikel pestisida dapat masuk ke tubuh melalui kulit. ${ }^{27}$

Oleh karena itu, diperlukan upaya meningkatkan kesadaran terhadap penggunaan APD lengkap penyediaan APD secara merata oleh perusahaan, serta menjaga kebersihan pasca terpapar pestisida diharapkan dapat meminimalkan efek buruk dari paparan pestisida.

\section{SIMPULAN}

Penelitian ini menyimpulkan: 1) Hasil analisis univariat menunjukkan bahwa pekerja mengalami penurunan kadar enzim kolinesterase 3,5\%. Pekerja yang berusia lebih dari 36 tahun sebesar 59,5\%. Jenis kelamin pekerja mayoritas laki-laki sebesar 81,4\%. Variabel tingkat pengetahuan pekerja baik sebesar $81,4 \%$. Variabel masa kerja di dominasi oleh pekerja dengan masa kerja kurang dari sama dengan 10 tahun sebesar $60,2 \%$. tindakan penyemprotan pada arah angin pekerja didominasi dengan melawan arah angin sebesar $61,9 \%$. Mayoritas pekerja memiliki frekuensi penyemprotan lebih dari 2 kali dalam seminggu yaitu sebesar 74,3\%. Mayoritas pekerja seudah menggunakan APD dengan baik sebesar $75,2 \%$, 2) Hasil analisis bivariat menunjukkan bahwa ada penggunaan APD dengan penurunan kadar enzim kolinesterase tenaga sprayer, dan tidak ada hubungan antara, jenis kelamin, tingkat pengetahuan, masa kerja, arah angin, dan frekuensi penyemprotan dengan penurunan kadar enzim kolinesterase tenaga sprayer, 3) Hasil analisis multivariat menunjukkan bahwa bahwa variabel yang berhubungan secara bermakna dengan kejadian penurunan kadar enzim kolinesterase adalah frekuensi penyemprotan dan penggunaan APD. Sedangkan variabel arah angin adalah variabel confounding. Variabel yang paling dominan berpengaruh terhadap terjadinya penurunan kadar enzim kolinesterase adalah penggunaan APD.

\section{DAFTAR PUSTAKA}

1. Kurniasih SA, Setiani O, Nugraheni SA. Faktorfaktor yang Terkait Paparan Pestisida dan Hubungannya dengan Kejadian Anemia pada Petani Hortikultura di Desa Gombong Kecamatan Belik Kabupaten Pemalang Jawa Tengah. J Kesehat Lingkung Indones. 2015;12(2):132-7.

2. Achmad U. Upaya Kesehatan Sektor Informal di Indonesia. Depkes RI. 1991.

3. Suhenda D. Karakteristik Individu, Waktu Penyemprotan Terakhir, Pengetahuan, Perilaku dan Kadar Cholinesterase Darah Petani di Kabupaten Subang Tahun 2006. FKM UI. 2007;
4. Zuraida. Faktor yang Berhubungan Dengan Tingkat Keracunan Pestisida pada Petani di Desa Srimahi Tambun Utara Bekasi Tahun 2011 [Internet]. Universitas Indonesia; 2012. Available from: http://lib.ui.ac.id/file?file=digital/20318363-SZuraida.pdf

5. Rahmawati YD, Martiana T. Pengaruh faktor karakteristik petani dan metode penyemprotan terhadap kadar kolinesterase. Indones J Occup Safety, Heal Environ. 2014;1(1):85-94.

6. Darmawan M. Efektivitas Peer Education Dalam Meningkatkan Pengetahuan Petani Holtikultura Tentang Keracunan Pestisida di Kelurahan Rajabasa Kota Bandar Lampung. Universitas Lampung; 2013.

7. Wicaksono $\mathrm{AB}$, Widiyanto $\mathrm{T}$, Subagiyo A. Faktor Internal Yang Berhubungan Dengan Kadar Enzim Cholinesterase Pada Darah Petani Kentang di Gapoktan Al-Farruq Desa Patak Banteng Kecamatan Kejajar Kabupaten Wonosobo Tahun 2016. J Kesehat Lingkung. 2017;36(3).

8. Zulkidi A. Hubungan Jenis Kelamin, Sikap, Lama, dan Frekuensi Penyemprotan Pestisida Dengan Kadar Enzim CHolinesterase Pasa Petani Sayur di Alahan Panjang Kabupaten Solok Tahun 2018. Universitas Andalas; 2019.

9. Mualim, Jubaidi, Widada A. Faktor-Faktor yang Berhubungan dengan Tingkat Keracunan Pestisida pada Tenaga Penjual Pestisida di Kota Bengkulu. J Media Kesehat. 2013;6(2):102-200.

10. Pawitra AS. Pemakaian Pestisida Kimia Terhadap Kadar Enzim Cholinesterase Dan Residu Pestisida Dalam Tanah. J Ilm Kesehat Media Husada. 2012;1(1):19-30.

11. Utami CU. Hubungan Pengetahuan, Sikap dan Tindakan Penggunaan Pestisida dengan Tingkat Keracunan Pestisida pada Petani di Desa Kembang Kuning Kecamatan Cepogo. 2016;112.

12. Budiawan AR. Faktor Risiko Yang Berhubungan Dengan Cholinesterase Pada Petani Bawang Merah Di Ngurensiti Pati. Unnes J Public Heal. 2014;3(1):1-11.

13. Rustia HN, Wispriyono B, Susanna D, Luthfiah FN. Lama Pajana Organosfosfat Terhadap Aktivitas Enzim Kolinesterase Dalam Darah Petani Sayuran. Makara Kesehat. 2010;14(2):95-101.

14. Samosir K, Setiani O, Nurjazuli N. Hubungan Pajanan Pestisida dengan Gangguan Keseimbangan Tubuh Petani Hortikultura di Kecamatan Ngablak Kabupaten Magelang. J Kesehat Lingkung Indones. 2017;16(2):63.

15. Osang AR, Lampus BS, Wuntu AD, Kesehatan F, Universitas M, Manado SR. Hubungan Antara Masa Kerja Dan Arah Angin Dengan Kadar Kolinesterase Darah Pada Petani Padi Pengguna Pestisida Di Desa Pangian Tengah Kecamatan 
Passi Timur Kabupaten Bolaang Mongondow. PHARMACONJurnal Ilm Farm. 2016;5(2):1517.

16. Tsani R, Setiani O, Dewanti N. Hubungan Riwayat Pajanan Pestisida Dengan Gangguan Fungsi Hati Pada Petani Di Desa Sumberejo Kecamatan Ngablak Kabupaten Magelang. J Kesehat Masy. 2017;5(3):411-9.

17. Afriyanto. Kajian Keracunan Pestisida Pada Petani Penyemprot Cabe Di Desa Candi Kecamatan Bandungan Kabupaten Semarang. Universitas Diponegoro; 2008.

18. Ramdan IM, Candra KP, Purwanto H. Factors Associated with Cholinesterase Level of Spraying Workers Using Paraquat Herbicide at Oil Palm Plantation in East Kalimantan, Indonesia. J Kesehat Lingkung Indones. 2020;19(1):16.

19. Lusiana D, Rozi F. Faktor Penyebab Keracunan Akut Penggunaan Pestisida pada Petani di Desa Ponoragan Kecamatan Loa Kulu Kabupaten Kutai Kartanegara. J Kesehat Masy Kesmas Wigama. 2015;1(2):60-7.

20. Neupane D, Jørs E, Brandt L. Pesticide use, erythrocyte acetylcholinesterase level and selfreported acute intoxication symptoms among vegetable farmers in Nepal: A cross-sectional study. Environ Heal A Glob Access Sci Source. 2014;13(1):1-7.

21. Dhananjayan V, Ravichandran B, Panjakumar K, Kalaiselvi K, Rajasekar K, Mala A, et al. Assessment of genotoxicity and cholinesterase activity among women workers occupationally exposed to pesticides in tea garden. Mutat Res Genet Toxicol Environ Mutagen [Internet]. 2019;841(February):1-7. Available from: https://doi.org/10.1016/j.mrgentox.2019.03.002
22. Nassar PPM, Ribeiro MG. Considerations for cholinesterase biomonitoring in flower and ornamental plant greenhouse workers. Sci Total Environ [Internet]. 2019;711(xxxx):135228. Available from: https://doi.org/10.1016/j.scitotenv.2019.135228

23. Garzia NA, Spinelli JJ, Gotay CC, Teschke K. Literature review: dermal monitoring data for pesticide exposure assessment of farm workers. J Agromedicine [Internet]. 2018;23(3):187-214. Available from: https://doi.org/10.1080/1059924X.2018.1448734

24. Franklin RC, McBain-Rigg KE, King JC, Lower T. Exploring the barriers and facilitators to adoption of improved work practices for safety in Exploring the barriers and facilitators to adoption of improved work practices for safety in the primary industries. 2015.

25. Cotton J, Edwards J, Rahman MA, Brumby S. Cholinesterase research outreach project (CROP): point of care cholinesterase measurement in an Australian agricultural community. Environ Heal A Glob Access Sci Source. 2018;17(1):1-11.

26. Magauzi R, Mabaera B, Rusakaniko S, Chimusoro A, Ndlovu N, Tshimanga M, et al. Health effects of agrochemicals among farm workers in commercial farms of Kwekwe district, Zimbabwe. Pan Afr Med J. 2011;ISSN: 1937-8688.

27. As'ady BA, Supangat S, Indreswari L. Analysis of Personal Protective Equipments Pesticides Usage Effects on Health Complaints of Farmers in Pringgondani Village Sumberjambe District Jember Regency. J Agromedicine Med Sci. 2019;5(1):31. 